\title{
POTENSI DAUN KATUK DALAM MENCEGAH KERONTOKAN RAMBUT
}

\author{
Muhammad Alka Fakhrizal*, Kurnia Hadi Saputra \\ Fakultas Kedokteran, Universitas Lampung, Jl. Prof. Dr. Ir. Sumantri Brojonegoro No.1, Gedong \\ Meneng, Kec. Rajabasa, Kota Bandar Lampung, Lampung, Indonesia 35145 \\ *alkafakhrizal.dr@gmail.com (+6282280305311)
}

\begin{abstract}
ABSTRAK
Alopesia berarti kerontokan rambut terlepas dari jenis penyebabnya. Alopesia dapat dibagi menjadi dua kategori utama: jaringan parut (cicatricial) dan non-jaringan parut (noncicatricial). Penyebab alopesia termasuk penuaan, kekurangan gizi, ketidakseimbangan hormon, penyakit dan stres. Salah satu tanaman yang memiliki potensi untuk mencegah kerontokan rambut adalah daun katuk karena kaya akan vitamin dan senyawa fenolik. Tujuan dari tinjauan pustaka ini adalah untuk melaporkan temuan ilmiah terbaru tentang manfaat kandungan daun katuk dalam mencegah kerontokan rambut dengan meningkatkan pertumbuhan, memperbaiki vaskular, dan menutrisi rambut. Metode yang digunakan dalam artikel berjenis tinjauan pusta ka ini adalah literature searching method melalui database NCBI dan Google Scholar. Tahun penerbitan sumber pustaka adalah dari tahun 2001 sampai tahun 2020 dengan 32 sumber pustaka dan 20 sumber yang dapat digunakan. Tema yang dikumpulkan terkait dengan kandungan daun katuk dalam mencegah kerontokan rambut atau alopesia. Hasil dari sintesis artikel yang telah ditemukan yaitu daun katuk bermanfaat dalam mencegah kerontokan rambut.
\end{abstract}

Kata kunci: alopesia, flavonoidsa, sauropus androgynous

\section{THE POTENTION OF KATUK LEAF IN ORDER TO PREVENT HAIRLOSS}

\begin{abstract}
Alopecia means hair loss regardless of the type of cause. Alopecia can be divided into two main categories: scar tissue (cicatricial) and non-scar tissue (non-cicatricial). Causes of alopecia include aging, malnutrition, hormonal imbalance, illness and stress. One of the plants that has the potential to prevent hair loss is katuk leaves because it is rich in vitamins and phenolic compounds. The purpose of this literature assessment is to report the latest scientific findings about the benefits of katuk leaves in the prevention of hair loss by promoting growth, improving vascularity, and nourishing hair. The method used in this article is this literature is a method of searching literature through the NCBI database and Google Scholar. The year of library resources is from 2001 to 2020 with 32 library sources and 20 usable sources. The theme collected is related to the katuk leaf collection in the prevention of hair loss or alopecia. As a result of the synthesis of articles that have been found, katuk leaves are useful in preventing hair loss.
\end{abstract}

Keywords: alopecia , flavonoid, sauropus androgynous

\section{PENDAHULUAN}

Rambut memiliki fungsi seperti pelindung dari paparan sinar matahari, termoregulasi, dan membantu proses transpirasi (Bufolli, 2014). Alopesia berarti kerontokan rambut terlepas dari jenis penyebabnya. Alopesia dapat dibagi menjadi dua kategori utama: jaringan parut (cicatricial) dan nonjaringan parut (non-cicatricial) (Monib, 2018). Alopesia non-jaringan parut masuk ke dalam enam kategori utama yaitu alopesia areata, alopesia androgenetik, telogen effluvium, 
Alopesia traumatik, tinea kapitis, anagen effluvium. Alopesia jaringan parut dibagi menjadi tiga jenis utama: tinea kapitis, alopesia musinosa, dan alopesia neoplastik (Ahmad et al, 2020).

Epidemiologi bervariasi tergantung pada penyebab alopesia dan jenisnya. Pada alopesia areata, prevalensinya adalah $0,2 \%$ tanpa kecenderungan ras atau seksual, dan dapat mempengaruhi kelompok umur. Alopesia androgenetik adalah kelainan umum yang menyerang $50 \%$ pria dan $15 \%$ wanita, terutama wanita pascamenopause (Rinaldi, 2019). Pada telogen effluvium, wanita cenderung lebih terpengaruh daripada pria. Pada tinea ckapitis, kejadiannya jauh lebih tinggi pada anak-anak (Owczarczyk-Saczonek, 2019). Pada penelitian yang dilakukan Legiawati sepanjang 2009-2011 di RSCM, terdapat Tiga penyakit kerontokan dan kebotakan rambut terbanyak berupa alopesia areata sebanyak 48 orang $(39,7 \%)$, efluvium telogen 40 orang $(34,5 \%)$ dan alopesia androgenetik 13 orang $(11,2 \%)$. Pada laki-laki paling sering ditemukan alopesia areata yaitu $56,8 \%$ (25 dari 44 orang), sedangkan pada perempuan terbanyak berupa effluvium telogen $(50 \%)$ (Legiawati, 2013).

Penyebab alopesia termasuk penuaan, kekurangan gizi, ketidakseimbangan hormon, penyakit dan stres. Stres oksidatif disebabkan oleh lingkungan, penuaan dan stres bertanggung jawab untuk onset dan perkembangan kerontokan rambut. Oksigen reaktif spesies (ROS) adalah faktor etiologi kunci untuk penuaan dari sel papila dermis. Tingkat ROS, seperti $\mathrm{H} 2 \mathrm{O} 2$ secara signifikan ditingkatkan selama kondisi stres (radiasi ultraviolet, obatobatan, merokok) (Trueb, 2009). Faktor lainnya yaitu kekurangan nutrisi yang dapat mempengaruhi struktur rambut dan pertumbuhan rambut (Emily dan Rajani, 2017).

Meskipun rambut rontok tidak mengancam jiwa, rambut rontok dapat memiliki efek mendalam pada kepercayaan diri dan kualitas hidup (Chaiyasut, 2012). Tatalaksana sesuai dengan etiologi dan jenis alopesia. Pada alopesia androgenetik, obat antiandrogen seperti finasteride bersama dengan semprotan minoxidil akan membantu, tetapi pada akhirnya pasien mungkin memerlukan transplantasi rambut. Dalam alopesia areata, kortikosteroid potensi sedang, bersama dengan semprotan minoxidil dan imunomodulator topikal seperti tacrolimus, dapat bermanfaat bagi pasien. Pada tinea kapitis, pengobatan utama adalah obat antijamur (Conic, 2018)

Dalam penanganan kebotakan secara farmakologis, Food and Drug Administration (FDA) hanya mengizinkan dua obat: Minoxidil dan finasteride. Minoxidil adalah produk topikal yang disetujui FDA. Minoxidil meningkatkan durasi fase anagen dalam folikel rambut. Hal ini menyebabkan stimulasi dan pertumbuhan folikel pada fase istirahat dan juga pembesaran folikel rambut. Selain itu, minoxidil yang digunakan secara topikal juga dapat menginduksi faktor pertumbuhan endotel vaskular yang menghasilkan vaskularisasi berkelanjutan dan peningkatan ukuran papilla dermal. Finasteride adalah inhibitor kompetitif 5-alfa hepatik dan reduktase jaringan. (Zito, 2017).

Beberapa efek samping lain yang timbul karena penggunaan dua obat sintetis ini adalah dermatitis, iritasi kulit atau alergi, gatal-gatal, dan eritema. Efek 
samping ini menyebabkan obat herbal sering merupakan pilihan untuk mengatasi kerontokan rambut dan merangsang pertumbuhan rambut. (Varothai, 2014).

Salah satu tanaman yang memiliki potensi untuk mencegah kerontokan rambut adalah daun katuk. Katuk atau. Daun katuk mengandung aktivitas antioksidan yang lebih tinggi. Komponen utama fraksi air katuk ( $S$. androgynous) adalah senyawa alkaloid daun katuk digunakan oleh masyarakat malaysia sebagai obat topikal yang dicampur dengan susu untuk mengatasi kerontokan rambut (Mustarichie, 2018). Daun katuk mengandung antioksidan bioaktif, seperti karotenoid, flavonoid, dan fitokimia lainnya. Fitokimia ini dapat mengurangi stres oksidatif, sehingga mengurangi risiko beberapa penyakit kronis (Hock, 2015). Selain itu daun katuk merupakan tanaman multivitamin yang mengandung vitamin A, E, seng, besi dan mineral yang baik untuk membantu pertumbuhan rambut (Platel dan Srinivasan, 2017). Untuk itu, tujuan dari penulisan penelitian berupa tinjauan pustaka ini adalah untuk mengetahui kandungan daun katuk terhadap pertumbuhan rambut dalam mencegah terjadinya kerontokan rambut atau alopesia.

\section{METODE}

Metode yang digunakan adalah literature searching. Sumber pustaka yang digunakan dalam artikel ini berjumlah 32 pustaka dan 20 jurnal yang dipakai dalam review manfaat daun katuk terhadap rambut, baik yang berasal dari buku, jurnal nasional atau internasional, maupun website. Penelusuran sumber pustaka dalam artikel ini melalui database NCBI dan Google Scholar dengan kata kunci Sauropus androgynous, alopesia, flavonoid. Pemilihan artikel sumber pustaka dilakukan dengan melakukan peninjauan pada judul dan abstrak yaitu membahas tentang potensi daun katuk pada rambut. Tahun penerbitan sumber pustaka dalam penulisan artikel ini adalah 2001 hingga tahun 2020.

\section{HASIL}

Ekstrak daun katuk telah memberikan aktivitas pertumbuhan rambut yang signifikan pada konsentrasi 10\%, 15\%, $20 \%$, dan $25 \%$. Dalam pengujian aktivitas fraksi daun katuk, fraksi air menunjukkan aktivitas pertumbuhan rambut yang positif dibandingkan dengan fraksi n-heksana, etil asetat, dan kontrol positif. Secara statistik, ditemukan bahwa efek pertumbuhan rambut diperoleh dari konsentrasi $10 \%$ ekstrak dan ditemukan bahwa aktivitas fraksi air daun katuk secara signifikan menunjukkan aktivitas pertumbuhan rambut yang lebih baik dibandingkan dengan n-heksana, etil asetat, dan kontrol positif (Mustarichie, 2018).

Hasil skrining fitokimia menunjukkan bahwa ekstrak etanol $90 \%$ daun katuk mengandung senyawa golongan alkaloid, triterpenoid, saponin, tanin, polifenol, glikosida dan flavonoid (Susanti, 2014). Sauropus androgynus Memiliki banyak nutrisi. Kandungan proteinnya lebih tinggi dari sayuran lainnya. Daun katuk merupakan sumber dari provitamin A, karotinoid, vitamin B dan C, protein dan mineral. Daun dewasa memiliki lebih banyak nutrisi dari daun muda. Tanaman ini terdiri atas air $82,45 \%$, protein $5,24 \%$, lipid $0,13 \%$ dan karbohidrat $4,86 \%$ dan asam askorbat $85,65 \%$ (Nahak, 2010).

Daun katuk memiliki kandungan besi daun ini berkisar antara 3,89-4,50 mg/100 g, sedangkan kandungan seng yang sama adalah antara 1,26-1,48 
$\mathrm{mg} / 100$ g. Daun katuk juga mengandung niasin 69-74 $\mathrm{mg} / 100 \mathrm{~g}$. Kandungan $\beta$-karoten atau vitamin $\mathrm{A}$ daun berkisar antara 7400-9250 $\mu \mathrm{g} / 100$ $\mathrm{g}$, sedangkan vitamin E berkisar antara 17,6 hingga 15,6 mg/100 g. Daun katuk mengandung alkaloid, yang kandungannya secara signifikan lebih tinggi pada daun tua $(1740 \mathrm{mg} / 100 \mathrm{~g})$ dibandingkan dengan daun muda (1439 mg/100 g) (Platel \& Srinivasan, 2017).

\section{PEMBAHASAN}

Tanaman katuk merupakan perdu yang tumbuh sepanjang tahun. Katuk memiliki daun majemuk genap, kecil, bulat, tersusun dalam tangkai daun. Anak daun berbentuk bulat dan ujung lancip, bagian tepinya rata. Warna permukaan atas hijau tua, sementara bagian bawahnya hijau muda. Bunga katuk berwarna kuning gelap hingga bintik merah, kecil, kelopak keras. Buahnya berbentuk bulat berwarna putih dan memiliki tiga biji (Rukmana dan Mukti, 2003).

Bahan aktif yang terkandung dalam daun katuk adalah asam lemak, klorofil, alkaloid, gliserol, asam benzoik. Selain itu juga kaya akan fenolik, flavonoid, dan asam askorbik, yang memiliki peran sebagai antioksidan (Samad et al, 2014). Selain itu daun katuk memiliki kandungan zat besi, seng, niasin, beta karoten atau provitamin A, vitamin $\mathrm{E}$, dan alkaloid (Platel dan Srinivasan, 2017). Sebagian besar komponen fraksi air dari daun katuk adalah flavonoid (Mustarichie, 2018).

Selain minoxidil (MXD) dan finasteride yang disetujui sebagai pengobatan kerontokan rambut, berbagai senyawa alami, termasuk flavonoid, telah diusulkan sebagai pengatur pertumbuhan folikel rambut pada penyakit yang berkaitan dengan pertumbuhan folikel rambut termasuk alopesia. Senyawa flavonoid, visnadin (VSD), hesperidin (HSP) dan baicalin (BC), aktif dalam pertumbuhan kembali pembuluh darah selama gangguan gagal jantung (Hiipakka et al., 2002).

Flavonoid telah dilaporkan memiliki potensi dalam promotor pertumbuhan rambut. Namun, hanya terbatas laporan yang tersedia dalam literatur yang menjelaskan mengenai mekanisme flavonoid sebagai promotor pertumbuhan rambut (Madaan, 2017).

Pada penelitian Bassino et al, secara in vitro peran selektif dari beberapa jenis flavonoid memiliki kontrol dalam pertumbuhan folikel rambut yang dimediasi oleh vaskular. Flavonoid dapat meningkatkan fosforilasi faktor pertumbuhan pembuluh endotel (Vacular Endothelial Growth Factor), salah satu faktor proangiogenik endogen yang paling kuat yang mengatur permeabilitas dan vasodilatasi pembuluh (Bassino et al., 2016).

Panjang dan lebar paling besar didapatkan dari folikel pada percobaan tikus yang diobati dengan glikosida flavonoid, hal ini mengidentifikasi glikosida flavonoid sebagai fitokimia bioaktif. Ekstrak flavonoid glikosida efektif dalam merangsang pertumbuhan rambut yang diukur dengan area folikel. Kinerja ekstrak glikosida flavonoid lebih tinggi dibandingkan dengan obat kontrol minoxidil, sedangkan glikosida steroid dan glikosida triterpenoid lebih rendah (Rambwawasvika, 2019).

Pada penelitian Hiipaka, menunjukkan bahwa flavonoid juga dapat merangsang pertumbuhan rambut dengan menghambat aktivitas enzim tipe II $5 \alpha$ reduktase (Hiipakka et al. 2002). Flavonoid selain berperan sebagai 
stimulan pertumbuhan rambut aktif juga memiliki kandungan antioksidan yang sangat baik. Antioksidan dapat mengurangi dampak radiasi ultra violet (UV) yang tidak menguntungkan pada serat rambut. Studi yang dilakukan oleh Signori mengungkapkan bahwa sinar UV merusak perkembangan rambut dengan menargetkan pigmen melanin dan fraksi protein (Signori, 2004). Stres oksidatif telah diidentifikasi sebagai hal yang penting faktor etiologi untuk induksi penuaan dan kematian sel papilla dermal pada lokasi pertumbuhan rambut (Naito, 2008).

Antioksidan seperti flavonoid dapat merangsang pertumbuhan rambut dengan menyebabkan relaksasi otot di pembuluh darah di sekitar folikel rambut sehingga memfasilitasi pasokan darah yang konstan dengan nutrisi ke sel-sel folikel rambut (Bassino et al., 2016). Vitamin dan antioksidan bermanfaat untuk mengurangi efek buruk pada serat rambut. Bahan yang paling efektif adalah antioksidan yang dapat mengganggu proses rantai radikal, membantu memperbaiki sistem kulit / rambut, melindungi terhadap kerusakan oksidatif (Mary dan Lupo, 2001).

Vitamin A mewakili kelompok yang larut dalam lemak retinoid yang termasuk retinol, retinal, dan ester retinil. sangat penting untuk visi, terlibat dalam fungsi kekebalan tubuh, dan diperlukan untuk pertumbuhan dan diferensiasi seluler. Vitamin A ada dalam makanan sebagai vitamin A (dari sumber hewani) dan sebagai provitamin karoten (bersumber dari tanaman). Kedua sumber tersebut harus diubah ke dalam bentuk aktifnya yaitu retinol dan asam retinoik dalam metabolisme intraseluler.
Kompleks vitamin B mencakup delapan zat vitamin yang tidak larut dalam air yaitu tiamin (B1), riboflavin (B2), niasin (B3), asam pantotenat (B5), vitamin B6, biotin (B7), folat, dan vitamin B12, yang membantu metabolisme sel (NHS, 2017). Peran dari asam folat dan vitamin B12 dalam asam nukleat memproduksi sugesti terhadap pertumbuhan folikel rambut. Adapun hal ini dibuktikan pada beberapa penelitian seperti pada penelitian yang membandingkan pasien alopesia areata dan pasien kontrol. Secara signifikan kandungan folat serum kelompok alopesia universal/total lebih rendah dibandingkan kelompok kontrol yaitu kerontokan rambut ringan (Harvard et al, 2018). Vitamin B5 telah digunakan selama bertahun-tahun dalam produk perawatan rambut karena berfungsi sebagai humektan, meningkatkan kadar air dan meningkatkan elastisitas rambut (Mary dan Lupo, 2001).

Senyawa fenolik dan vitamin dapat memberikan dukungan yang lebih spesifik untuk pemeliharaan kesehatan folikel rambut. Vitamin $\mathrm{C}$ meningkatkan pembentukan pembuluh darah, meningkatkan aliran darah di kulit kepala dengan merangsang sintesis VEGF (Semalty, 2011). Tocotrienol termasuk dalam keluarga vitamin E dan dikenal sebagai antioksidan kuat. aktivitas antioksidan tokotrienol yang membantu mengurangi peroksidasi lipid dan stres oksidatif di kulit kepala, yang dilaporkan terkait dengan alopesia (Lim et al, 2010).

Seng adalah elemen penting yang terlibat dalam berbagai fungsi biologis, termasuk sintesis DNA, ekspresi gen, kontrol hormon, reaksi enzimatik, dan proliferasi sel. Seng terlibat, baik sebagai elemen struktural atau faktor 
pengatur atau keduanya dan memiliki peran dalam aktivitas fungsional penting dalam folikel rambut. Seng mempercepat pemulihan folikel rambut dan merupakan penghambat kuat regresi folikel rambut. Banyak laporan menunjukkan peran seng dalam berbagai kasus alopesia androgenetik, dan beberapa pasien dengan alopesia memiliki seng dan beberapa kekurangan elemen lainnya (Plonka, 2005).

\section{SIMPULAN}

Kandungan pada daun katuk (Sauropus androgynous) bermanfaat dalam mengurangi kerontokan rambut atau alopesia.

\section{DAFTAR PUSTAKA}

Ahmad, M. A. A., Patrick, M. Z. (2020). Alopesia. Statpearls https://www.ncbi.nlm.nih.gov/boo ks/NBK538178/

Bhaskar, A., Ramesh, K. V. (2009). Wound healing profile of Sauropus androgynus in Wistar rats. J. Nat. Remedies, , 9(2), 159164.

Bufolli, B., Rodella, L. F., Rinaldi, F., Labanca, M., Sorbellini, E., Trink, A., et al. (2014). The human hair: From anatomy to physiology. Int $\mathrm{J}$ Dermatol;53:331-41.

Bassino, E., Antoniotti, S., Gasparri, F., \& Munaron, L. (2016). Effects of flavonoid derivatives on human microvascular endothelial cells. Natural Product Research, 30(24), 2831-2834.

Chaiyasut, C., Kumar, N., Rungseevijitprapa, W., Narkkhong, N.A., Suttajit, M. (2012). 5 $\alpha$-reductase inhibition and hair growth promotion of some Thai plants traditionally used for hair treatment. J Ethnopharm;139:765-71

Conic, R. R., Khetarpal, S., Bergfeld, W. (2018). Treatment of female pattern hair loss with combination therapy. Semin Cutan Med Surg. Dec;37(4):247-253

Emily L. G., Rajani, K. 2017. Diet and hairloss; effect of nutrient deficiency and supplement use. Dermatol Pract Concept. Jan; 7(1): 1-10. doi: $\underline{10.5826 / \mathrm{dpc} .0701 \mathrm{a} 01}$

Hiipakka, R. A., Zhang, H. Z., Dai, W, Dai, Q., Liao, S. (2002). Structure-activity relationships for inhibition of human $5 \alpha$ reductases by polyphenols. Biochem Pharmacol. 63:11651176.

Harvard, T. H. (2018). Three of the B vitamins: folate, vitamin $\mathrm{B} 6$, and vitamin B12. Boston, MA: Harvard T.H. Chan School of Public Health;. Accessed 8 Aug 2018

Khoo, H. E., Azlan, A., Ismaila, A. (2015). Sauropus androgynus leaves for health benefits: Hype and the science. Nat Prod J. ;5:115-23.

Legiawati, L. (2013). Jenis kerontokan rambut dan kebotakan pasien poliklinik kulit dan kelamin rsupn dr. cipta mangunkusumo tahun 2009-2011. Departemen Ilmu Kesehatan Kulit dan Kelamin FK Universitas Indonesia/RSUPN dr Cipto Mangunkusumo, Jakarta Vol. 40 No.4 159-163

Lim, A. B., Wong, J. W., Yuen, K. H. (2010). Effect of tocotrienol supplementation on hair growth in 
human volunteer. Tropical Life Science Research 21(2); 91-99

Madaan, A., Joshi, V., Kishore1, A, Verma1, R., Singh, A. T., Jaggi, M., Sung, Y. K. (2017). In vitro Hair Growth Promoting Effects of Naringenin and Hesperetin on Human Dermal Papilla Cells and Keratinocytes. American Journal of Dermatology and Venereology 2017, 6(3): 51-57 DOI: 10.5923/j.ajdv.20170603.02

Monib, K.M.E, Hussein, M.S., Kandeel W.S. (2018) The relation between androgenetic thin hair diagnosed by trichoscope and benign prostatic hyperplasia. J Cosmet Dermatol.

Mary, P., Lupo, M. D. (2001) Antioxidants and Vitamins in cosmetics, Clin. Dermatol. 19 467-473.

Mustarichie1, R., Hendriani, R., Triarini D. (2018). Anti-alopesia characteristic of Sauropus androgynus (L) Merr. ethanol extract and its fractions. Department of Pharmaceutical Analysis and Medicinal Chemistry, Faculty of Pharmacy, Universitas Padjadjaran, Indonesia.

Naito, A., Midorikawa, T., Yoshino, T., and Ohdera, M. (2008). Lipid peroxides induce early onset of catagen phase in murine hair cycles. Int J Mol Med.; 22:725729.

Nahak, G., Sahu, R. K. (2010). Free radical scavenging activity of multi-vitamin plant (Sauropus androgynus L. Merr.). Researcher 2 (11), 6-14.
Semalty, M., Semalty, A., Joshi, G. P., Rawat, M. S. (2011). Hair growth and rejuvenation: an overview. J Dermatolog Treat. Jun; 22(3):12332.

NHS. (2017). Vitamins and minerals: B vitamins and folic acid NHS choices. Washington, DC: National Health Service; https://www.nhs.uk/conditions/ vitamins-and-minerals/vitamin-b/

Owczarczyk-Saczonek, A., Wygonowska, E., Budkiewicz, M., Placek, W. (2019). Serum sickness disease in a patient with alopesia areata and Meniere' disease after PRP procedure. Dermatol Ther. Mar;32(2):e12798.

Plonka P. M., Handjiski, B., Popik, M., Michalczyk, D., Paus, R. (2005). Zinc as an ambivalent but potent modulator of murine hair growth in vivo- preliminary observations. Exp Dermatol. Nov; 14(11):84453.

Platel, K., Srinivasan, K. 2017. Nutritional profil of chekumaris, a less explored green leafy vegetable. The Indian Journal of Nutrition and Dietics. Volume 54 Issue https://doi.org/10.21048/ijnd.2017 .54 .3 .15765

Rukmana, R., \& Mukti, I. H. 2003. Katuk: Potensi Dan Manfaatnya. Penerbit Kanisius; Yogyakarta. ISBN 9792106774

Rinaldi, F., Marzani, B., Pinto, D., Sorbellini, E. (2019). Randomized controlled trial on a PRP-like cosmetic, biomimetic peptides based, for the treatment of 
alopesia areata. J Dermatolog Treat. Sep;30(6):588-593

Rambwawasvika, H., Dzomba, P., and Gwatidzo, L. (2019). Hair Growth Promoting Effect of Dicerocaryum senecioides Phytochemicals Internation Journal of Medicinal Chemistry. https://doi.org/10.1155/2019/7105 $\underline{834}$

Selvi, V. S., Bhaskar, A. Characterization of antiinflammatory activities and antinociceptive effects of papaverine from Sauropus androgynus (L.) Merr. Global J. Pharmacol., 2012, 6(3), 186-192.

Samad, A.P.A., Santoso, U., Lee, M. C., Nan, F. H. (2014). Effect of dietary katuk on growth nonspecific immune and disease resistance againts vibrio alginolyticus infection in grouper epinephelus coloides. Fish shellfish Immunol. 30; 582-89

Signori, V. (2004). Review of the current understanding of the effect of ultraviolet and visible radiation on hair structure and options for photoprotection. International Journal of Cosmetic Science, vol. 26, no. 4, pp. 219-219.

Susanti, N. M. P. Budiman, I. N. A, Warditiani, N. K. (2014). Skrining fitokimia ekstrak etanol 90\% daun katuk (Sauropus androgynus (L.) Merr.). Jurnal Farmasi Udayana, [S.1.], oct.. ISSN 2622-4607.

Trueb, R. M. (2009). Oxidative stress in ageing of hair. Int $\mathrm{J}$ Trichology.; $1: 6-14$

Varothai, S., Bergfeld, W.F. (2014). Androgenetic alopesia: An evidencebased treatment update. Am J Clin Dermatol;15:217-30

Zito, P. M., Hin, N. (2017). Minoxidil use in alopesia. J Dermatol Nurses'Assoc;9:264-7. 